\title{
Champion of Nature, Sustainability, and Education
}

Lucille Mazo*

Grant MacEwan University, Canada

\begin{abstract}
Drs. Rob de Vrind has been an advocate for nature and sustainability throughout his life. His need to be in nature is only slightly greater than his need to educate those around him about the importance of living a sustainable life. As the Senior Advisor for Sustainability, de Vrind provides critical information about sustainable choices and works collaboratively with the administrators, faculty, and students at the Koning Willem I College in 's-Hertogenbosch, Netherlands. His knowledge about sustainability is informed by his research in his field of biology. It is this combined knowledge base that has made him an intuitive champion of

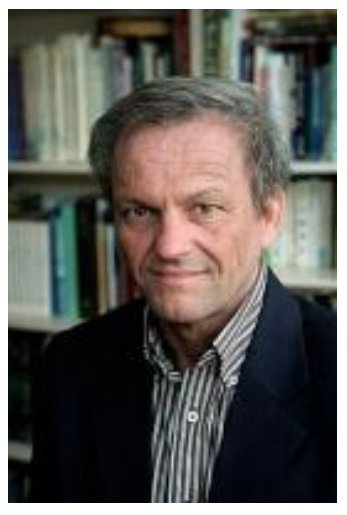
nature and a genuine leader in promoting sustainability in life, education, and industry.
\end{abstract}

\section{Nature's Researcher}

"Nature, the mirror of humankind" is Drs. Rob de Vrind's message when he talks about nature to those who listen to and read about his work. As a biologist, he understands the importance of doing research that produces original results and that adds to the body of knowledge within a discipline. After a

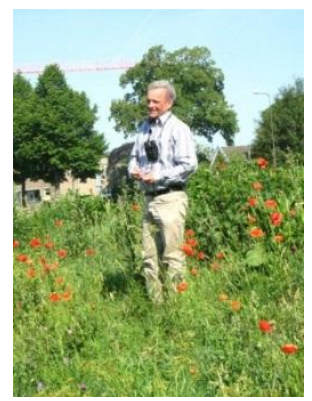


decade of discovery and field research, de Vrind (2002) published his book 'sHertogenbosch Zeldzaam Groen, which contained a detailed account of the plants and vegetation located within and around his city of 's-Hertogenbosch. More specifically, de Vrind provided critical information on the landscape and nature in and around the city, on the city's flora in 1848, and on the city's current flora and fauna.

\section{Plant Species Research}

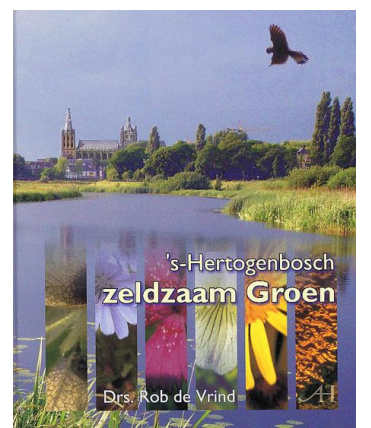

With a focus on the plant life surrounding 's-Hertogenbosch, de Vrind (2002) conducted numerous field excursions where he gathered and recorded data and information regarding the different species that grow in the region. As he walked the perimeter of the city, de Vrind applied his scientific knowledge and abilities to accurately identify and record the many plant varieties found in the immediate district. His in-depth attention to detail also resulted in the discovery and identification of some rare and new species. With countless hours of dedicated observation and rigorous notations, de Vrind documented many types of species that were entered into a database for current and future reference. This crucial information culminated in the development of a comprehensive table that listed 739 species of the current flora and fauna growing around the city, and resulted in the creation of a permanent record for the city (pp.119-125).

\section{Historical Research}

Along with his dedicated interest in the plant species of the region, de Vrind also developed a committed interest in his city's history. More specifically, his focus regarding historical research concentrated on the 1629 Siege of 's-Hertogenbosch. Supported by his detailed knowledge of the city's terrain obtained from his in-depth research of the regional plant life, de Vrind conducted numerous field trips into the area, noting the various historical landmarks that identified where and how the siege took place. Using a variety of observations, pictures, field notations, and mapping techniques, de Vrind depicted the layout of the city that was conquered in 1629 by Frederick Henry, Prince of Orange (van der Heijden, 2004, p.152). 
De Vrind's (2002) research resulted in the creation of a new map of the region that compared the city's landscape and demographics of 1629 with that of 2002. His map comprised two caches of information: 1) landmarks of 2002, and 2) historical landmarks of the 1629 Siege. To establish his comparison, de Vrind first created the base of his map by depicting the city's landmarks of 2002 which included forests, highways, streets, roads, water routes, and development areas. He then imposed the 1629 historic landmarks onto 's-Hertogenbosch's landmarks of 2002. The locations of the three critical forts that existed within this stronghold of 1629 were also positioned and illustrated: Fort Isabella, Fort Anthonie, and Fort Dieze. Also included on this map were accurate details of the locations of dikes, trenches, waterways, military companies, monasteries, churches, and windmills that were present during 1629 (pp.152-188).

A comprehensive explanation of the siege in relation to the map is included in a dedicated section of Peter-Jan van der Heijden's (2004) book Dagboek 1629: Ooggetuigen van het beleg van 's-Hertogenbosch (Diary 1629: Eyewitnesses to the siege of 'sHertogenbosch). De Vrind's historical information and map is also showcased in the Noordbrabants Museum where the public has access to this knowledge.

With his deep understanding and connection to nature and his strong scientific curiosity, de Vrind's need to demonstrate how humans should live on the planet and his need to determine how this goal should best be accomplished has naturally and intuitively brought him to the important areas of sustainable living, resources, and education.

\section{A Collaborative and Sustainable Voice in Education}

As the Senior Advisor of Sustainability at the Koning Willem I College in 's-Hertogenbosch, Netherlands, de Vrind epitomizes the role of an educator who champions and teaches sustainability within his institute. With a critical mandate to share his knowledge and experience, he is responsible for working with and advising the administrators, faculty, and students on the principles, approaches, and

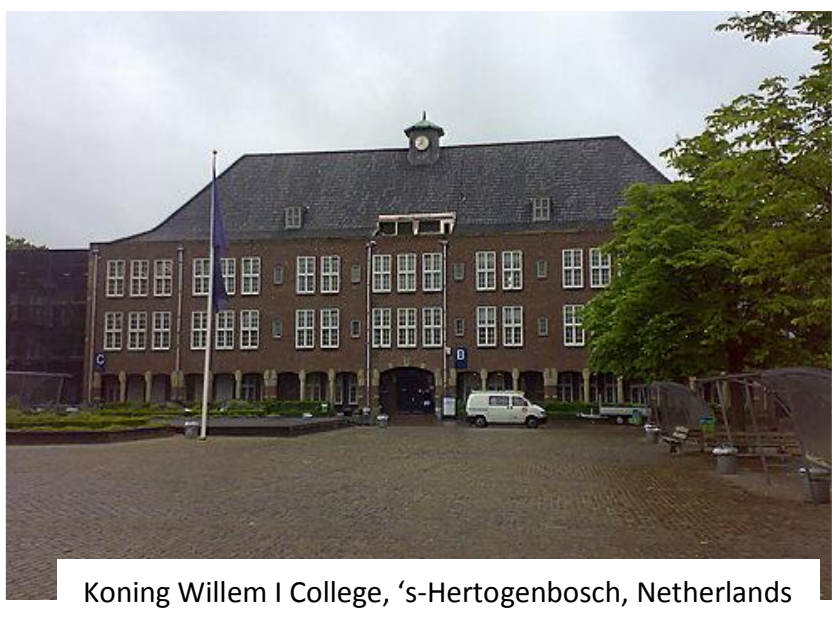


applications of sustainable living and how they can be integrated into the College's curriculum.

With a goal to integrate sustainability into the programs offered by the College, de Vrind works collaboratively with the faculty members and the students by advising them on innovative projects, by teaching sustainability as a guest lecturer in various classes, and by facilitating local, national, and international learning opportunities for students so that they can discuss, create, and disseminate information about sustainable living. An example of the College's commitment to sustainability is its annual Community Week where many students are engaged in creating and delivering sustainable projects within the local community.

This year's Community Week culminated on April 21, 2011, with Dr. Coen Free, Director of the College, joining the community in congratulating the student group that won the award for the most innovative and sustainable project. The long term success of the Community Week is a result of the College establishing fundamental partnerships between administrators, faculty, students, and community. The collaboration between these groups enables the College to uphold and implement the important learning objectives and goals of teaching students about sustainable principles and practices. In consultation with faculty, these goals and objectives continue to be reinforced throughout the year by de Vrind who promotes and teaches sustainability within various programs and courses throughout the College. With de Vrind at the forefront of these initiatives, it is little surprise that his dedication in promoting the education and implementation of sustainability won him a sustainability prize in the Netherlands. De Vrind received the prestigious Franc Houben Sustainability Award in 2007, recognizing him for his excellent work in this area.

De Vrind's ongoing work and research in education and sustainability is threefold: 1) he works with UNESCO to bring students and faculty together to discuss sustainable topics; 2) he works with a team of educators to present projects that support the framework of Cradle to Cradle (C2C); 3) he acts as a member of the Steering Committee for the DMBO (Duurzaam Middelbaar Beroepsonderwijs), whose mission is to ensure that sustainability is entrenched within all levels of an institution-the mission and vision statements, the curriculum, the management. 
UNESCO

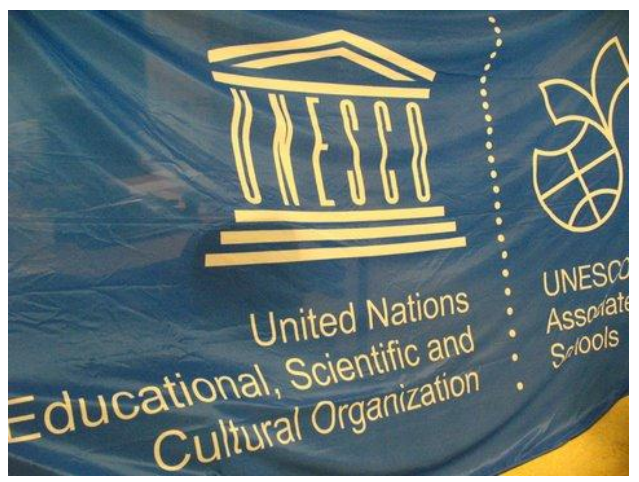

During the academic year of 2010-2011, de Vrind worked with a team to host an important and critical sustainability event supported by the international organization of United Nations Educational, Scientific and Cultural Organization (UNESCO). The Koning Willem I College is a designated UNESCO educational institute in the Netherlands and is a member of its Education for Sustainable Development (ESD) division. ESD is dedicated to integrating the concept of sustainability into all levels of education with a focus on promoting teaching and learning "that are environmentally sound, socially equitable, culturally sensitive and economically just" (UNESCO, 2011). ESD also ascribes to creating learning experiences that are hands-on in their approaches and that are related to local, national, and international communities focused on solving real and critical societal problems.

Using his skilful organizational abilities and his experience and knowledge in education and sustainability, de Vrind worked with a dedicated team to bring students and faculty together to discuss the important issue of water management and sustainability. The team's vision was supported by the UNESCO-IHE Institute for W ater Education, an organization that was established in 2003 by the Netherlands' government in partnership with UNESCO. This Institute's mandate is focused on "strengthening and mobilizing the global educational and knowledge base for integrated water resources management, and on contributing to meeting the water-related capacity building needs of developing countries and countries in transition" (UNESCO, 2011).
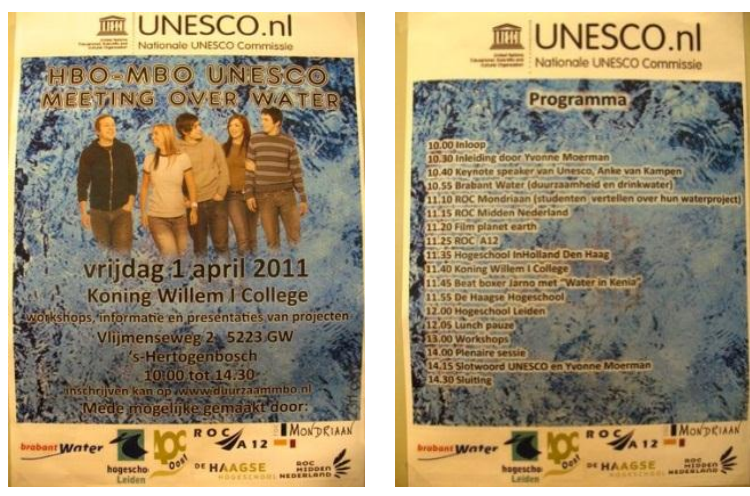

On April 1, 2011, the Koning Willem I College hosted a conference on water and sustainability: $H B O-M B O$ UNESCO Meeting on $W$ ater. The keynote speaker was Anke van Kampen, a representative of UNESCO. Students and faculty from various educational institutes across the Netherlands presented research projects that they had undertaken with respect to 
water and sustainability. Sharing and discussing these projects provided students, faculty, industry, and UNESCO with an opportunity to witness how educational institutes sanction, support, and promote sustainability through education and partnership. This conference also demonstrated how these institutes collaborated to ensure that students learned about sustainability so that they could transfer this knowledge into living more sustainably within their communities. De Vrind explained that this conference was only one of the ways that students could be taught about sustainability; Cradle to Cradle (C2C) was another.

\section{Cradle to Cradle (C2C)}

"Cradle to Cradle (C2C) is about innovation, quality, and beauty" (Braungart, 2011, p. 2). Based on award-winning research that began in the 1980's, the framework of Cradle to Cradle was developed by Dr. Michael Braungart and Dr. William McDonough who helped to establish the Environmental Protection Encouragement Agency (EPEA) in Hamburg, Germany. Since that time, this concept has been manifested and transformed into various forms, including implementation and practice within all levels of education.

In May 2011, the book Inspired by Cradle to Cradle (C2C) was published which included a mixed collection of both business and educational cases from $\mathrm{C} 2 \mathrm{C}$ leading countries. As a contributor to this book, de Vrind provided a relevant example of how the $\mathrm{C} 2 \mathrm{C}$ initiative has been integrated into the Koning Willem I College. Using the areas of construction, energy, and climate as a basis for his example, he explained how the three basic principles of the $\mathrm{C} 2 \mathrm{C}$ framework were present: 1 ) "waste=food (everything is a nutrient for something else)", 2) use current solar power income, 3) celebrate diversity (conceptual, bio, cultural) (p. 10).

To demonstrate how these $\mathrm{C} 2 \mathrm{C}$ principles were implemented within a classroom environment, de Vrind described how groups of four students were instructed to design a house in twenty minutes based on these three principles. Each student group was then directed to present the final design of their house and to explain how the $\mathrm{C} 2 \mathrm{C}$ principles influenced the group's design decisions. During these presentations, students were asked to consider the importance of re-thinking, re-organizing, re-planning, and re-scheduling resources so that they were more sustainable. Throughout this project, the framework of $\mathrm{C} 2 \mathrm{C}$ was reinforced-that everyone needed to start being sustainable in their choices at some point, even if these choices began as minor changes. By implementing these minor, more positive lifestyle decisions, the sum total of these smaller but important changes could then culminate in significant changes over a period of time. De Vrind further 
explained that "C2C was about thinking creatively and innovatively. Students who participated in this project were incredibly enthusiastic and were keen to follow it up in their educational programme. A first taste that promised more” (p. 34).

\section{Duurzaam Middelbaar Beroepsonderwijs (DMBO)}

De Vrind's involvement in sustainable education within his College is significant; therefore, it is with understanding that he continues his contribution to the knowledge of sustainability in other areas of his life. Constantly vigilant in finding ways to educate people on the importance of sustainable living, de Vrind applies his research, knowledge, and experience as a member of the Steering Committee for the Duuraam Middelbaar Beroepsonderwijs (DMBO) which is a nation-wide organization that is focused on promoting the teaching and integration of sustainability in educational programs. The DMBO is composed of a steering committee, a working group, and an advisory group.

The organization's mission is to ensure that sustainable development informs an institution's strategic decisions, curriculum creation and implementation, and management operations. As such, DMBO believes that strategic decisions need to include sustainable choices that are related to an institution's mission and vision statements; that the concept of sustainability needs to be integrated in curriculum development at all levels of education; and that sustainable management practices need to be considered in daily operations. Ultimately, DMBO believes that sustainability is achievable when management, supervisors, trainers, teachers, and students work collectively and collaboratively to ensure that sustainable practices are understood and promoted.

The DMBO provides assistance to all stakeholders by offering a support network, by ensuring that existing knowledge and understanding (including teaching materials) are available at the right time and place, by developing concrete products that are sustainable, and by providing follow up to educational institutions' requests for training, workshops, and materials. Examples of how DMBO promotes sustainable education and management include customized teaching materials, organized competitions for students, and awards and certificates. To learn more about DMBO and the work that they are collaborating on, visit http://www.duurzaammbo.nl/dmbo/web/ 


\section{A Champion Who Perseveres}

De Vrind's dedication to sharing his research knowledge and experience on sustainable living is evident. His insight into the interrelationship between education and real-world situations enables him to seek locally, nationally, and internationally those institutes, communities, and businesses that also believe in and promote sustainability. Innovative research, teaching, and implementation of sustainable projects are processes that he has and continues to provide for the students at the Koning Willem I College. The students, faculty, and businesses that collaborate with him are fortunate to have access to his deeply enduring commitment and belief in maintaining a sustainable planet.

* Author: Lucille Mazo is a faculty member who teaches at Grant MacEwan University in the Bachelor of Communication Studies degree program. She is the Managing Editor of Earth Common Journal and works with the Editorial Board and the Peer-Review Committee to select, edit, and publish the journal. She is a naturalist, has a passion for bird-watching, and the Netherlands is her favourite place to visit.

\section{References}

Braungart, M. (2011). Inspired by Cradle to Cradle: C2C Practice in Education. Hiteq, Hilversum, the Netherlands.

De Vrind, R. (2002). 's-Hertogenbosch Zeldzaam Groen. Adr.Heinen Uitgevers, 'sHertogenbosch.

Duurzaam Middelbaar Beroepsonderwijs (DMBO) (2011). Retrieved July 5, 2011, from http://www.duurzaammbo.nl/dmbo/web/

UNESCO (2011). Education for Sustainable Development (ESD). Retrieved June 30, 2011, from http://www.unesco.org/new/en/education/themes/leading-theinternational-agenda/education-for-sustainable-development/

Van der Heijden, P. (2004). Dagboek 1629: Ooggetuigen van het beleg van 's-Hertogenbosch. Adr.Heinen Uitgevers, 's-Hertogenbosch. 